\title{
Madagascar rosewood, illegal logging and the tropical timber trade
}

John L. Innes

\author{
University of British Columbia \\ Faculty of Forestry \\ Department of Forest Resources Management \\ 2424 Main Mall, Vancouver, BC, V6T 1Z4, Canada \\ E-mail:john.innes@ubc.ca
}

\begin{abstract}
Although deforestation rates in the tropics are reportedly slowing, the loss of both forest area and forest quality remains a significant issue for many countries. This is particularly true of Madagascar, where recent government instability has enabled a significant increase in the incidence of illegal logging of Dalbergia species from National Parks such as Marojejy and Masoala. The logs are exported with relative ease as export permits are being made available. While attempts have been made to improve the management of tropical forests, in 2005 , the International Tropical Timber Organization considered that only $7 \%$ of tropical production forests were being managed sustainably. Given the challenges associated with halting illegal logging at source, emphasis has shifted to the control of the trade in forest products. The Convention on the International Trade in Endangered Species provides a mechanism to restrict such trade, but the Madagascan Dalbergia species are not listed. In the USA, the recent amendments to the 'Lacey Act' could provide a significant disincentive to the import of illegally logged wood products, but it remains to be seen whether this Act can be enforced effectively.
\end{abstract}

\section{RÉSUMÉ}

Bien que les taux de déboisement sous les tropiques seraient à la basse, il n'en demeure pas moins que la perte de la couverture forestière et de la qualité des forêts restent des sujets sensibles pour de nombreux pays. Cela s'est avéré d'autant plus vrai à Madagascar que de récents troubles politiques ont été accompagnés par une augmentation significative de I'exploitation illicite de bois précieux, dont les bois de rose et les palissandres (Dalbergia spp.) dans les parcs nationaux comme ceux de Marojejy ou de Masoala. Les bois sont exportés assez facilement avec la délivrance de permis d'exportation dans un cadre législatif changeant. Dans le monde, il y a bien eu des essais d'amélioration de la gestion des forêts tropicales mais en 2005, I'Organisation internationale des bois tropicaux considérait que seulement $7 \%$ des produits sylvicoles issus des forêts tropicales étaient exploités de manière pérenne. Compte tenu de la difficulté à s'attaquer aux sources de l'exploitation illégale pour y mettre un terme, une attention particulière a été portée sur le contrôle du commerce des produits forestiers. La convention sur le commerce international des espèces de faune et de flore sauvages menacées d'extinction connue par son sigle CITES constitue un mécanisme permettant de limiter un tel commerce mais les espèces malgaches du genre Dalbergia pour les bois de rose et les palissandres ou Diospyros pour les ébènes ne figurent pas sur les listes de la CITES. Aux États-Unis, le nouvel amendement au 'Lacey Act' pourrait permettre de freiner de manière significative l'importation de produits forestiers exploités illégalement mais il faut voir si cette Loi pourra effectivement être imposée.

KEYWORDS: Rosewood, Dalbergia, illegal logging, World Heritage Convention, CITES.

MOTS CLEFS : bois de rose, Dalbergia, exploitation forestière illégale, Convention du Patrimoine Mondial, CITES.

\section{DEFORESTATION AND GOVERNANCE IN THE TROPICS}

Since the threat of an embargo on tropical forest products in the 1980s, considerable attention has been given to efforts being made to stop deforestation in the tropics. Between 2000 and 2010, 3.4 million ha of forest in Africa and four million ha of forest in South America (including some temperate forest) were converted to other forms of land use (FAO 2010). Although some have suggested that the latest figures from FAO suggest that rates of loss of tropical forests are slowing, the long-term data from the UN Food and Agriculture Organization (FAO 2009) suggest that the rates have changed little since the early 1980 s. Many tropical countries have enacted legislation to try and halt deforestation, but the flow of logs has continued, even from countries where all native forests are, in theory, protected. In such countries, ineffective enforcement or even the active collusion of government authorities have enabled illegal logging to continue and exports to take place. In some cases, including Madagascar, unstable political conditions have provided the opportunity for illegal logging to proliferate, and insecure governments focused on short-term priorities have often facilitated the logging.

Despite the numerous fora discussing illegal logging and other topics of interest to the international forest policy community over the past 25 years, little agreement has been reached over actions to deal with illegal logging, reduce deforestation or increase the proportion of the world's forests that are sustainably managed (Humphreys 2006). A 2006 report by the International Tropical Timber Organization (ITTO 2006) indicated that 


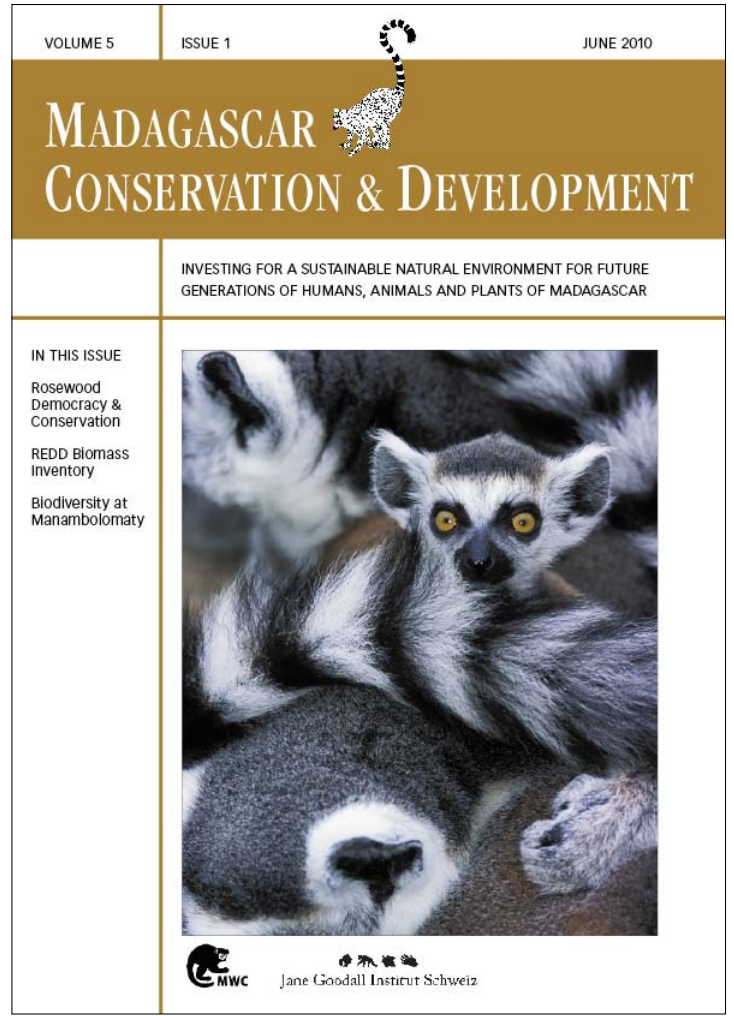

Madagascar Conservation \& Development is the journal of Madagascar Wildlife Conservation (MWC) and the Jane Goodall Institute (JGI Switzerland). It is produced under the responsibility of these institutions. The views expressed in contributions to MCD are solely those of the authors and not those of the journal editors or the publishers.

All the Issues and articles are freely available at http://www.mwc-info.net/en/services/journal.htm

\section{Contact Journal MCD}

info@journalmcd.net for general inquiries MCD funding@journalmcd.net for supporting the journal

Journal Madagascar Conservation \& Development Institute and Museum of Anthropology University of Zurich

Winterthurerstrasse 190

$\mathrm{CH}-8057$ Zurich, Switzerland

contact@mwc-info.net for general inquiries

Postfach 2701

CH-8021 Zürich, Switzerland

Logement 11, Cité Andohaniato

Antananarivo 101, Madagascar

info@janegoodall.ch for general inquiries JGI

\section{$2 \pi$ Jane Goodall Institut Schweiz}

Jane Goodall Institute Schweiz

Postfach 2807

8033 Zürich

switzerland 
only $7 \%$ of the 353 million ha of natural production forest in its producer member countries were sustainably managed. There is some debate over whether such figures actually represent sustainable management, as the presence of a management plan does not necessarily reflect whether or not a forest is being managed sustainably (Cerutti et al. 2008, Nasi and Frost 2009). The FAO has attempted to gather better information on this, but in their latest assessment, no response was obtained from countries representing $38 \%$ of the global forest area, so no accurate global figures can be reported (FAO 2010).

Some progress is evident amongst the regional 'Forest Law, Enforcement, and Governance' groups, and some important bilateral initiatives have emerged, especially as a result of the EU Action Plan for Forest Law Enforcement, Governance and Trade. Government procurement policies in consumer countries have emerged as a potential means by which the demand for illegally-sourced wood could be curbed, and an increasing number of countries have adopted these (Simula 2010). However, the extent of enforcement is unclear. Amongst the potential market-based mechanisms, certification was long intended to be a tool that would reward those in the tropics managing their forests sustainably and to separate products derived from well-managed forests from the products of deforestation (Bass et al. 2001), but uptake of this procedure has been disappointingly slow. Recent evidence suggests that even in certified forests, illegal logging is still occurring, suggesting significant problems with the auditing process (Nsoh 2009). In the following, I concentrate on one aspect of the international timber trade, illegal logging. In particular, I focus on the trade in rosewood originating from Madagascar.

\section{ILLEGAL LOGGING}

There are many difficulties with the concept of illegal logging, not least its definition (Tacconi 2007, Brown et al. 2008). However, many take a fairly straightforward approach and define it as the harvest, transport, sale or purchase of timber in contravention to national laws. As such it includes timber taken without a license, timber taken from protected areas, timber stolen from private property, timber taken without paying the correct stumpage and a range of other forms of abuse. The 'U.S. Lacey Act', to be enforceable, has provided the definitions to be used in the USA. Modified to be specific to logging, the definition of an illegally sourced product includes the theft of logs, the taking of logs from an officially protected area, the taking of logs from other types of 'officially designated' areas recognized by a country's laws and regulations, the taking of logs without, or contrary to, the required authorization, the failure to pay appropriate royalties, taxes or fees associated with the log's harvest, transport or commerce, and the contravening of laws governing export or trans-shipment. For a contravention of the Lacey Act to occur, a person must trade this illegally sourced product in U.S. interstate or foreign commerce. This requires an offender to "import, export, transport, sell, receive, acquire, or purchase" the product. Much will depend on the efficacy of the mandatory species labelling, which it will be an offence to violate, but checking that the wood really does come from a specific species will be extremely difficult without detailed laboratory testing.

The 2008 amendment to the Lacey Act has provisions for prosecutions through either criminal or civil action, or through forfeiture. Civil penalties of up to \$US 10,000 are being applied to any party who, in exercising due care, could reasonably have been expected to know that trade in the plant or wildlife in question was illegal. Civil penalties are also applied to any party that knowingly commits an offence associated with false labelling or knowingly violates the declaration requirements. The size of the penalty depends on the nature, circumstances, extent, and gravity of the offence, and the culpability and ability to pay of the offender. Forfeiture also occurs in civil cases. Any illegal timber or products made from illegal timber brought into the U.S. may be seized whether or not the person involved knew about the illegal nature of the product.

Criminal prosecutions under the Lacey Act are divided into misdemeanours and felonies. The division is based on the knowledge of the offender and the intent (mens rea) to commit a crime. The crime is classed a misdemeanour if the government determines that the offender should have known that the handling of the goods was illegal. In such cases, the offender is expected to have exercised due care in determining the potential illegality of the goods. Individuals are subject to fines of up to \$ US 100,000 and organizations to fines of up to \$ US 200,000 and / or imprisonment for up to one year. Felonies occur when the government can show that the offender knew, or was generally aware, that handling of the product was illegal. The value of the product must exceed \$US 350. Penalties include prison sentences of up to five years, and fines of up to $\$$ US 250,000 (individuals) or \$US 500,000 (corporations).

An often-used excuse to justify commerce in illegally sourced materials is that if they are purchased on the open market, it is the responsibility of the source country to police its own territories. In some cases, this argument is reinforced by the logs passing through another country - the forestry equivalent of money-laundering. For example, in the case of Madagascar, many rosewood logs shipped from ports such as Vohémar and Toamasina pass through the ports of Mayotte or Mauritius (Barrett et al. 2010), where they are then sold on to the European Union, China and elsewhere (Global Witness and Environmental Investigation Agency 2009). Within an international context, law enforcement is essentially a national responsibility. It is reiterated in Principle 3 of the Convention on Biological Diversity "States have, in accordance with the Charter of the United Nations and the principles of international law, the sovereign right to exploit their own resources pursuant to their own environmental policies, and the responsibility to ensure that activities within their jurisdiction or control to not cause damage to the environment of other States or of areas beyond the limits of national jurisdiction". However, under the Lacey Act, it will be an offence to trade in illegally-sourced products, even when the authorities of the source country have knowingly or unknowingly allowed the trade to occur.

A key issue is enforcement. On March 24, 2010, the transitional authority in Madagascar issued a decree prohibiting all exports of rosewood and other precious timber for a period of two to five years (decree no. 2010-141). However, it appears that the decree has not been completely endorsed by the government, enabling logging in national parks, such as Masoala National Park, to continue (Bohannon 2010). In addition, the current decree allows rosewood exports to occur with a ministerial order. This has created considerable uncer- 
tainty which, combined with the local difficulties of enforcement, have created ideal conditions for illegal logging to flourish.

\section{LOGGING BANS AND CITES}

Trade in endangered species is officially controlled through the Convention on International Trade in Endangered Species (CITES). However, only one species of rosewood, the Brazilian rosewood (Dalbergia nigra), is listed under Appendix I of CITES, indicating a ban on all international trade in the species. Two further species ( $D$. retusa and $D$. stevensonii) have their Guatemalan populations listed under Appendix III, which indicates that a party has requested cooperation from other countries to prevent unsustainable or illegal harvesting. Some of the demand for rosewood from Madagascar can be directly attributed to the shortage of supply of Brazilian rosewood, an unintended consequence of the CITES ban in its trading. With 48 species of rosewood (Dalbergia spp.) present in Madagascar (Bosser and Rabevohitra 1996, 2005, Du Puy et al. 2002), any separation of logs belonging to listed species from those that are unlisted will be difficult (Bohannon 2010). Consequently, a listing under CITES will need to cover all the Dalbergia species present in Madagascar if it is to be enforceable. Other species are also threatened, including the ebonies (Diospyros spp.). With the ebonies, it is even uncertain how many species there are in Madagascar, with many specimens awaiting formal identification and naming.

CITES has not always been an effective way to ensure the conservation of trees. A good example is provided by broadleaf mahogany (Swietenia macrophylla). This species is widely distributed throughout the Neotropics, but has been placed on the IUCN Red List of Threatened Species, where it is classed as 'vulnerable', meaning that it is considered as facing a high risk of extinction in the wild in the near future. The species was initially listed under Appendix III by Costa Rica in 1995, but other countries did not follow suit for several years, meaning that imports from some countries were legal, while those from costa Rica required special certificates. This resulted in substantial difficulties of enforcement (CITES Management Authority of the USA 2001, TRAFFIC 2002). It was moved to Appendix II of CITES in 2003, a classification that restricts exports, but still enables export certificates to be issued if it can be demonstrated that "the anticipated impact of current or proposed harvests on species' population status will be non-detrimental to the species in its role in the ecosystem" (CITES 2009). No import certificates are required if the authorities of the importing country are satisfied that trade in the species will not be detrimental to the survival of the species in the wild (which seems inconsistent with the IUCN listing). Importing countries must also be satisfied that the wood has been obtained legally. Individual countries have experienced many problems in managing the logging of the species and in restricting exports (CITES 2008a, b), and the ongoing debate over this species demonstrates just how difficult enforcement of trade restrictions on timber species can be.

The history of the ban on rosewood exports is interesting. A qualified ban was introduced by government decree in 2000 (decree no. 11832/2000). Despite the ban, there has been a steady amount of logging and export, normally through ministerial permits (Schuurman and Lowry 2009). This was reversed on 28 January 2009, when a new decree authorized rosewood exports. With a military coup occurring in March 2009, the new government allowed exports to continue and it was only with the March 2010 decree that logging of rosewood was again banned. However, as mentioned above, it remains possible to get a ministerial decree to enable the export of rosewood from Madagascar. The lifting of the ban enabled massive logging operations to take place, much occurring in the Marojejy and Masoala National Parks (Schuurman and Lowry 2009, Wilmé et al. 2009a). Increased logging also took place in Makira Natural Park, although this classification does allow some logging to occur under normal circumstances. The first exports occurred as early as April 2009 (Débois 2009).

In trying to regulate any trade, an important problem will be the difficulty of identifying individual species. Even labelling the wood 'Madagascar rosewood' will not necessarily help since in the timber trade, this term is used ambiguously. For example, the website of Winwood Products (a UK company) states "Madagascar Rosewood is also called Kali, Kararo, Landojan, Landosan M'boul, Mukali, Mukangu, Muna, N'Kali, osan, Tanganyika Nuss and Tutu. The species occur from Guinea to Ethiopia, and is also found in Zambia and Gabon" (Winwood 2010). A quick internet search revealed numerous rosewood items for sale in the U.S. made from Madagascar rosewood, particularly acoustic guitars, as well as lumber (from Dalbergia baroni, known as 'palissandre'). The difficulties of enforcing any ban are currently being tested: The Nashville plant of Gibson Guitar Corporation is under investigation by the U.S. Fish and Wildlife Service for violations of the Lacey Act, allegedly for the use of Madagascar rosewood. This is the first investigation of a case involving wood made under the 2008 revision of the Lacey Act. Gibson Guitar has previously been recognized for its recognition of the problems associated with illegal logging, and has been sourcing mahogany from legal, certified sources in Honduras and Guatemala (Rainforest Alliance 2010). The U.S. Fish and Wildlife Service will have to demonstrate that illegalities involving other wood have occurred, providing an interesting test case of direct relevance to the trade in Madagascar rosewood. As Gibson Guitar has a chain of custody certificate issued by the Forest Stewardship Council (FSC), and has been subject to annual inspections by the FSC, the case also demonstrates the potential difficulties associated with the voluntary forms of wood product regulation.

While there may be difficulty in identifying the species that logs in a port are derived from, or the sources of timber at a manufacturing facility, there is a sound understanding of who in Madagascar is cutting the rosewood, who is selling it, who is transporting it and who is buying it (Wilmé et al. 2009a). This contrasts with many other illegal logging situations around the world, where the attribution of responsibility is much more complex. The potential financial income from the trade in illegal rosewood is substantial, and the 1,137 container-loads known to have been exported in 2009 would have sold for more than \$ US 200 million (Wilmé et al. 2009a). This presents problems for the Madagascar authorities, as there are substantial stockpiles of illegally harvested rosewood logs (Wilmé et al. 2009b).

A major destination for tropical hardwoods is China. Madagascar rosewood is no exception, and there is a high demand for this product for the manufacture of traditional Chinese furniture (Wilmé et al. 2009a). Much of this is sold within China, but some is exported to the USA, and will be subject to the restrictions imposed by the Lacey Act. China is currently in the process of introducing certification programs 
that have clear chain of custody requirements, but if North America is a good example, very little effort will be made to ensure that furniture products come from legal and sustainably managed (i.e., certified) sources. However, there are also a range of other destinations for Madagascar rosewood, including North America and Europe.

\section{THE FUTURE}

The ongoing problems associated with the logging and export of rosewood from Madagascar has illustrated the many challenges faced by those attempting to put a halt to illegal logging and ensure the long-term survival of individual tree species. Clearly, designating a reserve is insufficient if there is no capacity or will to enforce the reserve. Similarly, designating a species as protected will also fail if there is no enforcement. The international forest policy community has been ineffective in both stopping deforestation and encouraging the more sustainable management of forests. International bodies such as the Food and Agriculture Organization of the United Nations do not have the power to ensure enforcement, and its reliance of contributions from individual member states severely limits its ability to monitor what is occurring. The International Tropical Timber Organization could play a greater role, but so far has not done so, again partly because of its organizational structure. As a first step, Madagascar needs to have its rosewood species listed by the Convention on International Trade in Endangered Species.

While governmental and inter-governmental processes can be of value, there is an urgent need for the independent monitoring of forests. To a certain extent, this is being done on a voluntary basis through the certification movement. However, the case of Gibson Guitar Corp. described above will demonstrate just how effective this is. There is a strong case for a more rigorous, independent process of forest monitoring with some form of legal powers. Such processes are extremely difficult to implement when they impinge on national sovereignty, as demonstrated by the failure to establish a legally-binding global forest convention to date. Organizations such as the World Resources Institute in Washington D. C. may be a suitable alternative, provided that they can demonstrate a non-partisan approach to their work.

For Madagascar, an important step would be for the government of Madagascar to request that Marojejy and Masaola National Parks, both of which are UNESCO World Heritage sites, be included in the 'list of World Heritage in danger'. This would be in accordance with Article 11(4) of the 'Convention Concerning the Protection of the World Cultural and Natural Heritage'. This convention has the capability of forming an effective means to ensure the protection of important natural forests worldwide, but so far has not been very effective in doing so. Greater international attention needs to be given to this and other conventions, and mechanisms to ensure that signatory countries respect them are needed.

National mechanisms will only occur when there is a political will for the actions. At present, the government of Madagascar has not indicated that it is willing to shut down the export of rosewood, creating the opportunity for the continued degradation of forests where rosewood occurs, including those supposedly protected in reserves. Clearly, pressure needs to be brought to bear on the Madagascar government so that the long-term benefits of forest conservation will become more apparent.

\section{REFERENCES}

Barrett, M. A., Brown, J. L., Morikawa, M. K., Labat, J.-N. and Yoder, A. D. 2010. CITES designation for endangered rosewood in Madagascar. Science 328: 1109-1110. (doi: 10.1126/science.1187740)

Bass, S., Thornber, K., Markopoulos, M., Roberts, S. and Grieg-Grah, M. 2001. Certification's Impacts on Forests, Stakeholders and Supply Chains. International Institute for Environment and Development, London.

Bohannon, J. 2010. Madagascar's forests get a reprieve - but for how long? Science 328: 23-24. (doi: 10.1126/science.328.5974.23)

Bosser, J. \& Rabevohitra, R. 1996. Taxa et noms nouveaux dans le genre Dalbergia (Papilionaceae) à Madagascar et aux Comores. Bulletin du Museum national d'Histoire naturelle, $4^{\mathrm{e}}$ sér, 18: 171-212.

Bosser, J. \& Rabevohitra, R. 2005. Espèces nouvelles dans le genre Dalbergia (Fabaceae, Papilionaceae) à Madagascar. Adansonia 27, 2: 209-216.

Brown, D., Schreckenberg, K., Bird, N., Cerutti, P., Del Gatto, F., Diaw, C., Fomété, T., Luttrell, C., Navarro, G., Oberndorf, R., Thiel, H. and Wells, A. 2008. Legal Timber: Verification and Governance in the Forest Sector. ODI, London.

Cerutti, P. O., Nasi, R. and Tacconi, L. (2008). Sustainable forest management in Cameroon needs more than approved forest management plans. Ecology and Society 13, 2: 36 [online] <http://www.ecologyandsociety.org/vol13/iss2/art36/>.

CITES. 2008a. Progress Report of the Joint ITTO-CITES Timber Project: First Regional Meeting. Presented to the $17^{\text {th }}$ Meeting of the Plants Committee, Geneva (Switzerland), 15-19 April 2008. Document 16.1.2. <http://www.cites.org/eng/com/PC/17/E-PC17-16-02.pdf> accessed 21 May 2010.

CITES. 2008b. Progress Report on the Implementation of the Action Plan for Big-leaf Mahogany. Presented to the $17^{\text {th }}$ Meeting of the Plants Committee, Geneva (Switzerland), 15-19 April 2008. Document 16.1.1. Available at <http://www.cites.org/eng/com/PC/17/E-PC17-16-0101.pdf>.

CITES. 2009. International expert workshop on non-detriment findings. Report presented to the $18^{\text {th }}$ meeting of the Plants Committee, Buenos Aires (Argentina), 17-21 March 2009. Document PC18 Doc 14.1. Available at <http://www.cites.org/eng/com/PC/18/E-PC18-1401.pdf>.

CITES Management Authority of the USA. 2001. National Report of the United States of America to the First Meeting of the Mahogany Working Group, Santa Cruz de la Sierra, Bolivia, 3-5 October 2001. MWG1 Document 8.9. Available at <http://www.cites.org/eng/prog/ MWG/MWG1/E-MWG1-Doc-08-09-US.pdf>.

Débois, R. 2009. La fièvre de I'or rouge saigne la forêt malgache. Univers Maoré 13: 8-15.

Du Puy, D. J., Labat, J.-N., Rabevohitra, R., Villiers, J.-F., Bosser, J. and Moat, J. 2002. The Leguminosae of Madagascar. The Royal Botanic Gardens, Kew, U. K.

FAO. 2009. State of the World's Forests 2009. Food and Agriculture Organization of the United Nations, Rome, Italy.

FAO. 2010. World's Forests 2010 - Key Findings. Food and Agriculture Organization of the United Nations. Available at <http://www.fao. org/forestry/static/data/fra2010/KeyFindings-en.pdf>.

Global Witness and Environmental Investigation Agency 2009. Investigation into the Illegal Felling, Transport and Export of Precious Wood in SAVA Region Madagascar. Available at <http://www.globalwitness. org/media_library_detail.php/887/en/field_investigation_into_illegal_logging_in_madaga>.

Humphreys, D. 2006. Logjam: Deforestation and the Crisis of Global Governance. Earthscan, London.

ITTO (2006). Status of Tropical Forest Management 2005. ITTO Technical Series Mo. 24, ITTO, Yokohama, Japan.

Nasi, R. and Frost, P. G. H. 2009. Sustainable forest management in the tropics: Is everything in order but the patient still dying? Ecology and Society 14, 2: 40. [online] <http://www.ecologyandsociety.org/vol14/ iss $2 / \operatorname{art} 40 />$ 
Nsoh, W. 2009. Controlling Illegal Logging and the Trade in Illegally Harvested Timber: An Assessment of Forest / Timber Certification as an Instrument to Ensure Legal and Sustainable Timber Production. VDM Verlag Dr. Müller, Saarbrücken, Germany.

Rainforest Alliance. 2010. Statement in response to the United States Fish \& Wildlife Service's investigation of Gibson Guitar Corporation. Available at <http://www.rainforest-alliance.org/forestry.cfm?id=gibson_usfws> accessed on 22 May 2010

Schuurman, D. and Lowry II, P. P. 2009. The Madagascar rosewood massacre. Madagascar Conservation \& Development 4, 2: 98-102.

Simula, M. 2010. The Pros and Cons of Procurement. Developments and Progress in Timber Procurement Policies as Tools for Promoting the Sustainable Management of Tropical Forests. Technical series No. 34 International Tropical Timber Organization, Yokohama, Japan.

Tacconi, L. (ed.) 2007. Illegal Logging: Law Enforcement, Livelihoods, and the Timber Trade. Earthscan, London.

TRAFFIC. 2002. CITES Appendix III implementation for big-leafed mahogany Swietenia macrophylla. TRAFFIC On-line Report Series 1. Available at: $<$ www.traffic.org/forestry-reports/traffic_pub_forestry4.pdf $>$. Accessed 22 May 2010

Wilmé, L., Schuurman, D., Lowry II, P. P. and Raven, P. H. 2009a. Precious trees pay off - but who pays? An update. Document prepared for the COP15, Copenhagen Meeting, 7-15 December 2009. Available at <http://www.illegal-logging.info/uploads?Posterrosewoodupdate09D ec2009.pdf>

Wilmé, L., Schuurman, D. and Lowry II, P. P. 2009b. A forest counterpart fund: Madagascar's wounded forests can erase the debt owed to them while securing their future, with support from the citizens of Madagascar. Lemur News 14, in press.

Winwood 2010. <http://www.winwood-products.com/eng/timber-products/ veneer/madagascar_rosewood.htm> accessed 21 May 2010 